\title{
Analysis of Barriers to Successful of Computer Information Systems in Iran (Case Study: Iranian Banks)
}

\author{
Habib Roodsaz \\ Associate Professor, Faculty of Management, University of Allameh Tabatabaei, Tehran, \\ Iran \\ E-mail: dr.roodsaz@gmail.com
}

\begin{abstract}
Amirhossein behrooz (Corresponding author)
Assistant Professor of Master of Business Administration Department,Payam Noor University, Iran

E-mail: behrooz.a@pnurazavi.ac.ir
\end{abstract}

Amirhesam behrooz

M.S. Candidate of Executive Management of Business Administration, University of Tehran, Tehran, Iran

E-mail: ah.behrooz@ut.ac.ir

Received: April 14, 2013 Accepted: May 15, 2013 Published: December 25, 2013

doi:10.5296/bms.v4i2.3530

URL: http://dx.doi.org/10.5296/bms.v4i2.3530

\begin{abstract}
Impact on management, organization and technology in the failure or success of information systems in organizations and institutions is one of the issues that information systems and information technology researchers constantly have to review it. Unfortunately, in Iran has been done yet a research for recognizing the identity of a computer system and efficiency of scientific research. Knowledge of the reasons for the failure of a computerized information system, cause to awareness and care managers and design team and will focus on potential
\end{abstract}


weaknesses. Managers support the strengthening and weakening of the driving and inhibiting factors in the design and implementation and also development of information systems and preparation hardware and software infrastructure is one of the key points of failure and success is an information system.

This study is applicable and causal in its nature. Sample with 35 system and equals with number of statistical community members and it includes all computer systems that have the mission to provide banking services to customers. Indices test questionnaire using multiple regression analysis has been done the Iranian state banks. . Statistical analysis tools are also included Pearson correlation and beta coefficient. The findings of this study shows that the main reason for the failure of most information systems in Iranian banks is Issues and problems that the components of the operating and management strategies, expectations, complexity - the risk is occurring.

Keywords: Information systems, Failure, Management factors, Organizational factors, Technological factors, Iranian banks 


\section{Introduction}

Introducing and adjustment of an information system has powerful management, organizational and technological impacts. . This will change how the function and interaction of individuals and various groups. How to change the definition, access and use information resources for handling often leads to a new distribution of authority and the power. This change causes the internal resistance and opposition, and could lead to the decline of a system that otherwise would be good. Very large percentage of information systems in solving problems or delivering benefits are just failing. The organizational change process towards making the system correctly unnoticed. Making a successful transformation system requires careful transition management.

For effective management of organizational change About introducing a new information system, the design and implementation process Should be studied and considered. Implementation refers to all organizational activities with the acceptance, management and a common method devised as a new organizational system. Implementation process, systems analyst is a change agent. Analyst does not only develop technical solutions but also defines configurations, interactions, job supports and new organizational power relations of various groups. Analysts in the development process, the role of the catalyst are responsible for ensuring that these are the organizations implementing such changes has been made with the nature of the failure or success of the original form. And the role and effect of managers, the nature of organizational performance and effectiveness of existing technology, puts information systems in the range from failure to success (Laudon, 2007). Given the importance of successful implementation of information systems projects and the high failure rate of these projects, this question has risen that what factors have a major role in the failure of information systems projects? And how prevent the failure of information systems projects?

In order to answer the above questions, this article aims to identify reasons for failure in the computer information systems in Iranian banks and has been developed ways to reduce their failure rate.

Information systems are more than computers. Effective use of information systems requires a knowledge organization, management and information technology. The critical success factors and failure of information systems projects in three general categories has been studied: Management, , technology, and organizational factors (Laudon, 2007).

Management factor includes components such as stability-education, support, selection, strategy, and technology factor includes components such as complexity-risk, system impact, system scheme, infrastructure and organizational factor includes components such as conflicts on comments, readiness, manner, expectations. Expert Survey questionnaires were used to identify this component. The conceptual model is presented for information systems failure and after analyzing the data, recommendations is presented for successful implementation of such projects and also for future studies in this field. 


\section{Research Literature Review}

Information systems today are very much reviewed and this is due to expand its use throughout the world. Information systems can be defined such that the Single type of system that is working to apply the information by any combination of six different functional processes: Receive, transmit, store, retrieve, manipulate, and display information.

Information systems innovatively with change in business processes, improve their efficiency and productivity. Therefore, in developing countries due to scarcity of available resources and the need for efficient use of their information systems is very important to the project. And maximum effort should be done in order to minimize the failure of information systems. Discouragement and lack of willingness to undertake and implement new information systems projects, consequently previous failures is second factor that is essential for study the reasons failure. Otherwise we cannot imagine a bright future (Alter, 1999).

Development of information systems in developing countries takes place in various fields. Due to having sufficient financial and technological resources of the state, the dominant area in the development of information systems is E-government that as head of information systems development in these countries will rise. Iran as a developing country that is growing increasingly moving towards the development, It is not excluded from this and because the enjoyment of economic and social development, deployment of information systems has been upward. On the other hand, review of research literature shows that very little research has been conducted in developing countries about the reasons for the failure of information systems and also we cannot comply entirely reasons of failure in developed countries with reason of failure in developing countries. For that reason, this article examines these factors in developing Iran.

Our review of the literature shows that there is no single definition for the failure and almost as many different opinions, there are various definitions. Although with little negligible, we can found the same season in all definition. Wilson and his colleagues believe, that the various definitions of failure of information systems provided by the researchers, this mentality has created that Almost every project to potentially be considered a failure (Wilson.M \& Howcroft.D, 2002). One of the biggest problems facing, for the definition of consensus is that the success or failure of information systems from the perspective of different stakeholders and different ways to look system (Dix et al., 2004). Also, because the facing with different demands of various stakeholders. Also different scales will be needed to assess the influence of system for different groups of stakeholders (Seddon et al., 1999). Another problem in examining the reasons for failure, reluctance of organizations to talk about is the failure. Instead of being more eager to explore the reasons, they they tend to avoid because fear of being weakness and costly decision, (Cole, 1997; Oz \& Sosik; 2000), something that we have seen it many times in the data collection.

But before define and review a failure, it is important to note that two issue: First, time efficiency that we evaluate the MIS. Studies show that success or failure of information 
systems can assessed in Short-term or direct effects or long-term and indirect effects on the efficiency. Second is the level at which to measure success or failure. Information systems will be evaluated at three levels. These three levels are: (1) the organizational level (firm); (2) the process (functional) and (3) individual-level (user). At the organizational level, the success or failure of information systems related organizational performance measure used primarily by tools. This includes an increase in market share, profitability, operating efficiency, operating cost and return on investment. In the process, information systems is evaluated by efficient use of resources and reduce process cycle time. The scale included operational efficiency of functional parts, lesser costs and targeting processes are well understood. Finally, at the individual level (user), information systems can be measured by the users' perception of desirability and satisfaction. This stage is defined by user satisfaction and utility systems (Garrity and Sanders, 1998).

Now you can look up some definitions of failure:

If an information system development, operation stops, System fails to meet expectations of potential and actual supporters, and then it has failed (Sauer, 1993).

A project that fails to do on the basis of predetermine the budget shall be deemed a failure (Standish Group, 1994).

Project which its time and budget exceed the originally prescribed for it, cannot be termed successful (Taylor, 2000).

The project has been canceled or project to can't achieve the business objectives, has failed (Standish Group, 2006).

"Savr" listed five types of failure for information systems that include:

1 - Failure to achieve predetermined objectives

2 - Failure Process: When has risen that can't create a system according to determine the budget or the time;

Failure of interaction: When users are unsatisfied with the system and they have lack of incentive to work with the system, this failure occurs.

4 - Failed Expectations: Each project begins with ideas and expectations of its stakeholders, but in the end may not meet all these demands.

5 - Failed end: occurs when a project is canceled before the final delivery. Project termination is the last thing that may happen in the failure of a project, and this is when there is no hope for achieving goals (Sauer, 1993).

Heeks in another classification consider the two modes of failure information system:

a. Complete failure: in this type of failure, a system is not implemented or abandoned immediately after implementation. 
b. Partial failure: in some cases, a system is implemented and used at a time; however, the system fails to achieve certain goals. In other words, the system only covers part of its objectives (Heeks, 2003).

Since, according to reports in the literature, the attention to reasons of information systems failure, has improved relative information systems projects, In following we review the reasons for failure in any of the information systems of management, technologies and operating factors.

\section{Factors of Information Systems Failure}

\subsection{Management Agent}

\subsubsection{Heading Stability and Literacy}

One of the important properties of information systems that have a role on information system failure is management instability. Many information systems projects when they suffered successive changes in senior executive management or management information systems are unstable. Changes in senior management and replace them again destroy the Focus and support for the success of a system administrator who needs it. In the study of "Jiang" and "Klein" this index as one of four key factors in the failure has been introduced.

Believing to designed system definitely will add to management and organizational support of information system. In fact when there is no believe and enough commitment among senior managers to Information Systems to implement has nothing but failure. On the other hand believe in the effective management of information systems is considered an outstanding success factor. According to studies, belief and commitment of managers at all stages of development and growth of information systems is essential, so that lack of this cause to big failure. When senior management has committed itself to a project, consequently, any action that is necessary and at any level At all stages of project development and implementation will do.

For a full understanding of information systems, managers have a broader dimension of managerial, organizational and IT know and action in providing business solutions to environmental challenges by using an appropriate information system. This broader understanding of information systems referred to as information literacy (lavdn 2001).

\subsubsection{Support}

Manager can have a positive step in removing barriers for implementation of information system. Managers can facilitate Matters related to implementation of the system with Factors such as promoter elements that to strengthen human resources, grant and in kind and cash rewards. The manager should attempt to identify barriers and remove barriers, another step forward in the implementation of information systems. The manager should be implemented with financial support and logistical information system to pave roads. To prevent failure of information systems, all the facilities including manpower, finance, 
information and ... Should be mobilized. In general, if any underlying managers withhold their support for those systems, there will be no chance to implement and sustain the system. (Irani, Sharif, \& Love, 2001; Standish Group, 1999)

No doubt the directors, as MIS strategic plan for your organization are considered, with the certain schedule and money into, not only will be pay to financial and logistical support, But also receive periodic reports from the project team, in order to eliminate obstacles hindering the action will do and And notifying managers of the current trend, with the support of their support facilitate promoter affairs.

\subsubsection{Selection}

One of the mistakes in the implementation of information systems is lack of proper analysis of cost - profit. "Glass" outline the use of new technology is a huge mistake. He argues that a $\$ 100$ million project with a new technology should not be initiated unless this technology before it is used in a $\$ 10$ million project and a $\$ 10$ million project should not be started unless they first completed project is \$1 million. (Glass 1991)

According to a study by Astandysh and took over 365 companies, 7/52 percent of projects have suffered a partial failure. Although these projects have been implemented but since gone beyond the scheduled time, they can't be successful. Prolonging time of Design or implementation may due to cancel the entire project because the Strategies may be changed during this time. Other environmental factors such as new technologies, changing needs of users and ... Can actually make inefficient project (Standish Group, 1994).

Often, information system design takes place, but something is not done to start implementation. At design, a parallel infrastructure should be specified and implemented.because The appropriate place to implement the system, the new organizational chart, new jobs and ... Is required. It should be scheduled so that upon completion of the design, implementation steps to begin.( Kitiyadisai, 2000)

\subsubsection{Strategy}

Information system goals align with organizational goals, one of the influential elements in the success of information systems. Lack of information systems goals align with organizational goals an cause to other failures such as lack of management support and commitment that was mentioned earlier. Strategic analysis of key factors for success of an information system by analysts need is a strategic project that is the introduction of information systems (Laudon, 2007).

The goals and strategies must first determine, in writing, and shall be approved, and then according to their information systems are designed. If the organization does not consider the costs of changing to a new system, the benefits of IT investments will decline. Introduce or change a strategy includes severe organizational and manneral impact and Defines how different groups of people and their tasks or to interact. How to define and interpret the changes in technology assessment and its application in the enterprise resource management 
often leads to a new distribution of power and the authority (Law \& Perez, 2005).

\section{2 The technology facto}

\subsubsection{Complexity - Risk}

Complexity is defined differently in different texts. According Bakariny definition, the complexity can be understood as various sectors interaction that can be created from various functions and depended ways. Thus you have a system that is composed of several components. Each of these components, have the dependencies of each sections and each sections could have been independent and have specific impact on the whole system. Each of the components has not only internal dependencies, but also accepts other components of the system. Although each of these components are independent and has its own internal dependencies but a small change in each of the inner components can have different effects on the entire system and Sometimes project forward to fail. Complexity is risk factors for failure of information systems (Barki, Rivard, \& Talbot, 1993). A way for success of project is to reduce complexity. The study has shown that the broadest prominent feature of the failed systems is high degree of inherent complexity of these projects (British Computer Society, 2003). Systems mainly differ in terms of size, scope, technical and organizational components and complexity. Some systems have a high level of risk and probability of failure is very high. Some systems have a high level of risk and probability of failure is very high. The level of project risk are Influenced by factors such as project size, project structure and level of technical skills, personnel information systems and project team (Laudon, 2007). The more size of a larger project, the more number of executive manpower, much time is allocated for the implementation and the more organizational units involved, and project risk will be higher. Very large projects, about 50 to 75 percent failure rate is higher than other projects, because such projects are complex and are difficult to control. Also to solve a larger problem, there is need for further breakdown of project components into small project which this increases the complexity of interactions between the components (AlSharif, Walter, \& Turky, 2004; Schmidt, et al. 2001).

\subsubsection{The System Impact}

Information systems with information processing, often limited to the transfer, recycling, storage, display help to the business processes. Information systems are trying to change existing business processes to improve them and make it automatically. (Nauman et al.2009). In fact the information systems are tools for increase efficiency and effectiveness in organizational processes are being carried out. Information systems should be designed so that furthermore increase speed, improve the quality of the decision. The design and implementation of the system should always consider these questions: does system reaction out operation with high speed and accuracy? Is it increases our effectiveness and efficiency? Has create excellence and distinction in a competitive market for us? Has increased our power to make decisions? 


\subsubsection{System Schema}

Managers often fail to define their information needs. Sometimes the analyst and designer also unable to define the information need of final system consumers. In addition, information system users who have poor knowledge are not able to express their needs. Inability of the designer in an interview on this subject will rise. Because of this, there is a need to knowledge professionals are experienced enough. For these reasons most systems suffer from shortcomings in their information needs for properly defined (IT Cortex, 2005).

Data in the system may have a high level of carelessness and inconsistency. Also, some data are not well defined. It should be clear that any data are logged in which organizational unit. The information in certain fields may be filled with errors or ambiguous, or they can't be properly segregated for the purpose of the organization. Information needed to do a specific task may be due to incomplete data are not available (Laudon, 2007).

For satisfying our needs, the system should be following an appropriate model. For this reason, analysts and operational planners need to research career in modeling, have sufficient mastery. The main concept of technology is nothing but what is the model design. The Model obtains the data and makes them our expected output (Braa \& Hedberg, 2000).

\subsubsection{Infrastructure}

One of the main reasons for the failure of information systems is weaknesses in the system infrastructure. Especially in Iran, network and telecommunication lines have their own problems and organizational do not enjoy infrastructure necessary for successful implementation of information systems.

Insufficient number of Internet service providers, lack of extensive features and powerful software, network problems in the context of information systems, telecommunications, and satellite and computer networks are inadequate and low bandwidth Internet lines, including problems that impact the IT project failure (Akhavan, Mohamadlou and Habibi, 1383).

\subsection{Organization Factor}

\subsubsection{Conflict on Comments}

Conflicts on comments and disputes arising from the lack of integrated language between the analyst, designer and programmer and a weak interaction between the employer and enforcement, lack of commitment of each party involved in the project information system.

A source of conflict refers to lack defining of the role of each of the parties involved in the design and implementation. To avoid a conflict, the best solution is that each analyst and designer should be aware of the responsibilities and roles. In other words, the analyst and designer should be somewhat familiar with each other's activities. Conflict mainly has risen because lack of understanding each other (DeLone \& McLean, 2003).

Client and host conflict could be because the contract provisions are not well defined and the 
costs of payment processing and delivery time not recorded as precise and clear in the contract.In fact, one of the main tasks of the team manager is to choose correctly members.

\subsubsection{Readiness}

Organizations should be prepared to implement its information systems and then attempt to run the system. Jobs must be redefined for this purpose. Department should be created to maintain information systems to handle the affairs of the catch. Note that with entering organization's information systems, organizational structure will also change (Laudon, 2007).

Another reason for the failure of information systems is lack of departmental information systems in organizations. A strong association that deals with the policy and monitors the implementation of information systems is one of the mechanical principles for large organizations (Montealegre \& Keil, 2000).

Also, when designing the information system should take the time to educate employees and assign users.

\subsubsection{Manner}

Interaction failure: The failure of information systems is an indirect assessment of failure information systems that if the system is exposed to large amounts of user interaction, is successful and if the user does not use it or not use it correctly, is unsuccessful. In this view, problems such as difficulty in assessing the quality of interaction is in progress and it is usually consider as user satisfaction. For example one question rise that Do you need time to evaluate user satisfaction that he has used the system to or measure the amount of data transferred? (Arabi and Izadi, 2003).

Lack of coordination and cooperation between managers, designers and programmers create our own - their attitude. In some cases it is not clear who is responsible for performing a task. That's why each of the groups does not accept responsibility. Usually each group considers their successes and failures due to poor performance of its functions of other groups (Arabi and Izadi, 2003). An organization in operational and strategic standpoint requires encouraging participating all its members and stakeholders. There is always a strong belief that stakeholder participation is essential for successful systems (Cash \& Fox, 1992).

\subsubsection{Expectations}

System failure is not primarily due to technical deficiencies, but the lack of attention to those who are involved in or affected by it will be desired. People involved and affected by any system, they expect of that system that should be considered.

Failure can be expected as a tool for evaluation of information systems used. The problem there is that at a certain time, all participants haven't expressed their expectations. Their expectations have not yet thought of or perhaps because their expectations do not understand yet (Lyytinen and Hirschheim, 1987). In addition, any characters not include all requirements. What really needed is the system design must provide potential and imperfect users 
expectations. Another problem is that it increases the risk of failure is that While in the new millennium a system is designed and used, Expectations of participants will be enhanced and refined (Arabi and Izadi, 2003).

Lack of attention of designer to demands and interests of target group refers to backgrounds, different interests and priorities that designer and user are both involved in it. This is called the gap between the user - designer (Laudon, 2007).

In some cases due to lack of user awareness of the needs and demands of the system, after implementation, stating that the system is not what was intended and it does not meet his demands (Vandersluis, 1997).

\section{Empirical Study and Discussions}

According to the research topic in computer information systems as reasons for the failure of Iranian banks, the main concept of the reasons for the failure of information systems was considered as the dependent variable.

\subsection{Research Conceptual Model and Hypotheses}

Conceptual model using the theoretical framework derived from research articles, books and using the Delphi technique and looking at the issue of localization experts, including managers, analysts, designers and developers of information systems organizations has been developed by researchers as following conceptual model. In an attempt to model the concept, elements and components into a single logical network, developed, described and shown to be complete.

It must be noted that from 42 items obtained from the various articles, finally with expert opinions in the survey, 12 components were selected which are classified as the independent variables, in terms of management, organization and technology factors. Thus the hypothesis presented in this form that causes of failure of computer information systems is in management, organization or technology factor. 


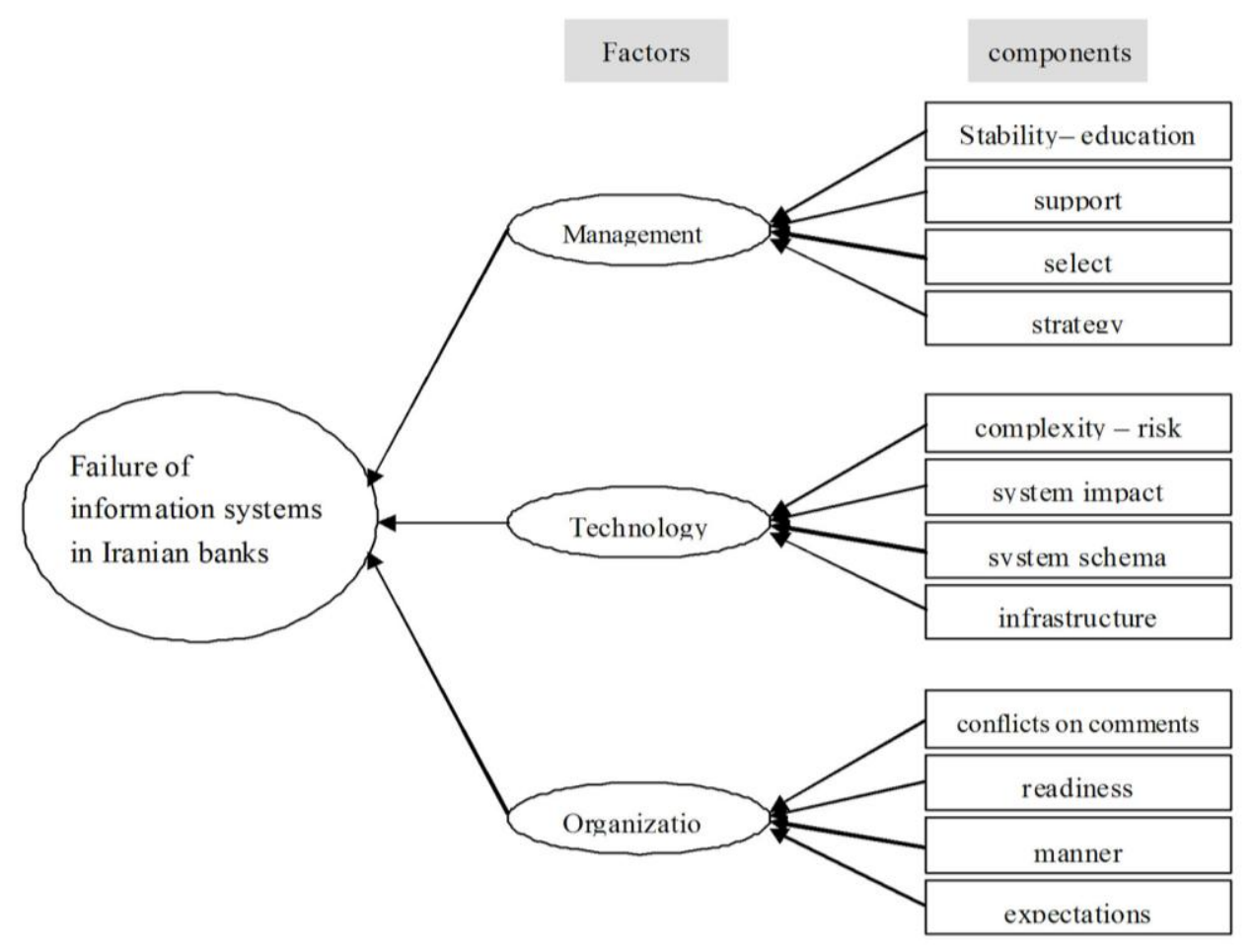

Figure 1. Research Conceptual model

\subsection{Research Method}

The nature of this research is applicable and its purpose is explanatory. In this study we followed the reasons of failure of Iran's banks in the computer information systems. Research questions are "why" type ones and our research strategy is deductive and verified theory process. Conceptual model for the study is relations and integrated concepts with a certain level of credibility that its background is obtained by the researchers using the above articles and research. Also, a conceptual model that represents the mechanism or structure heir explanatory hypothesis is composed of elements and components and using the theoretical framework. Sample to study equals with statistical community members, and including all banking computer systems that have the mission to provide banking services to customers. For data collection, a questionnaire package using Likert's type was designed includes 41 items. In this research, for assessing the validity of research reliability of questionnaires, Cronbach's alpha coefficient is used. Statistical analysis tools are also included Pearson correlation coefficient to show homogeneity and heterogeneity between the components and the factors together, and the beta coefficient.

\subsection{Reliability Test}

In this study after designing of desired case, for Better measurement and evaluating each of these concepts, items desired and select the appropriate case; Cronbach's alpha test was used. The empirical rule, Cronbach's alpha should be at least $7 / 0$ is the scale has to be considered reliable. Cronbach's alpha case desired size obtained from 928/0, which shows the compatibility and reliability case designed to have desired. 
Table 1. The Cronbach's alpha test

\begin{tabular}{|l|l|}
\hline Cronbach's alpha & Case number \\
\hline .928 & 37 \\
\hline
\end{tabular}

\section{Analysis of Research Data}

In this section the gathered data by using statistical indicators at different levels of correlation and regression coefficients was analyzed. The three levels are:

- Component impact analysis level of each of the three factors separately on the failure of information systems;

- analysis level of all three factors on the failure of information systems;

- Level impact analysis of each of the three factors on the failure of information systems.

5.1 Component Impact Analysis Level of Each of the Three Factors Separately on the Failure of Information Systems

In order to realize the relationship between dependent and independent variables and the impact of each independent variable on the dependent, regression coefficient index is used. At first Analysis of the four factors influencing rate on the failure of management information systems in organizations are investigating.

Table 2. Impact Analysis Management Agent components on the dependent variable

\begin{tabular}{|c|c|c|c|c|}
\hline Model & $\mathrm{R}$ & R Square & $\begin{array}{c}\text { Adjusted R } \\
\text { Square }\end{array}$ & $\begin{array}{c}\text { Std. Error of the } \\
\text { Estimate }\end{array}$ \\
\hline 1 & $.797 \mathrm{a}$ & .635 & .587 & .59044 \\
\hline
\end{tabular}

a. Predictors: (Constant), manage 4, manage 3, manage 2, manage 1.

b. Dependent Variable: $\mathrm{m} 1$

Table 2 shows the four component's correlation with the dependent variable $(80 / 0 \approx \mathrm{R})$. This means that there has been high correlation between Management Agent independent variables with the dependent variable. The coefficient of determination (R2) is approximately equal to $63 \%$ that this means from $100 \%$ of the total value of the dependent variable changes, $63 \%$ is related to these four components.

Also, with consider to beta coefficients in Table 3, strategy component (manage 4) has the most influence on the failure of information systems in Iranian banks. 
Table 3. Analysis of the Management Agent component on the dependent variable

\begin{tabular}{|c|c|c|c|c|c|c|}
\hline \multirow{2}{*}{\multicolumn{2}{|c|}{ Model }} & \multicolumn{2}{|c|}{$\begin{array}{c}\text { Unstandardized } \\
\text { Coefficients }\end{array}$} & \multirow{3}{*}{$\begin{array}{c}\text { Standardized } \\
\text { Coefficients } \\
\text { Beta } \\
\end{array}$} & \multirow{3}{*}{$\begin{array}{r}\mathrm{t} \\
\\
\\
.208\end{array}$} & \multirow{3}{*}{$\begin{array}{l}\text { Sig. } \\
\\
.837 \\
\end{array}$} \\
\hline & & \multirow{2}{*}{$\begin{array}{r}\text { B } \\
.103\end{array}$} & \multirow{2}{*}{$\begin{array}{c}\text { Std. } \\
\text { Error }\end{array}$} & & & \\
\hline \multirow[t]{5}{*}{1} & (Constant) & & & & & \\
\hline & Stability-education & .074 & .140 & .090 & .532 & .598 \\
\hline & support & .253 & .217 & .231 & 1.166 & .253 \\
\hline & selection & .122 & .239 & .096 & .512 & .612 \\
\hline & strategy & .469 & .138 & .499 & 3.408 & .002 \\
\hline
\end{tabular}

a. Dependent Variable: $\mathrm{m} 1$

Table 4 shows the effect of the variable component of operating system failure data. In this table $\mathrm{R}$ is $71 / 0$, which indicates a very high correlation of the dependent variable with four components.

Table 4. Analysis of the organization operating components of the dependent variable

\begin{tabular}{|c|c|c|c|c|}
\hline Model & $\mathrm{R}$ & R Square & $\begin{array}{c}\text { Adjusted R } \\
\text { Square }\end{array}$ & $\begin{array}{c}\text { Std. Error of the } \\
\text { Estimate }\end{array}$ \\
\hline 1 & $.715 \mathrm{a}$ & .511 & .446 & .68368 \\
\hline
\end{tabular}

a. Predictors: (Constant), org 4, org 3, org 2, org 1.

b. Dependent Variable: $\mathrm{m} 1$

Table 5 also shows that components with the highest expectations of the beta coefficient, has the greatest impact on information systems is the failure rate and Ingredient of the readiness has no effect on the dependent variable. 
Table 5. Analysis of the operating components of the dependent variable

\begin{tabular}{|c|c|c|c|c|c|c|}
\hline \multirow{2}{*}{\multicolumn{2}{|c|}{ Model }} & \multicolumn{2}{|c|}{$\begin{array}{c}\text { Unstandardized } \\
\text { Coefficients }\end{array}$} & \multirow{3}{*}{$\begin{array}{c}\text { Standardized } \\
\text { Coefficients } \\
\text { Beta }\end{array}$} & \multirow{3}{*}{$\begin{array}{r}\mathrm{t} \\
.072\end{array}$} & \multirow{3}{*}{$\begin{array}{r}\text { Sig. } \\
.943\end{array}$} \\
\hline & & \multirow{2}{*}{$\begin{array}{r}\text { B } \\
.049\end{array}$} & \multirow{2}{*}{$\begin{array}{c}\text { Std. } \\
\text { Error }\end{array}$} & & & \\
\hline \multirow[t]{5}{*}{1} & (Constant) & & & & & \\
\hline & $\begin{array}{l}\text { Conflicts on } \\
\text { comments }\end{array}$ & .477 & .195 & .406 & 2.449 & .020 \\
\hline & readiness & .000 & .183 & .000 & -.001 & 1.000 \\
\hline & manner & -.068 & .194 & -.060 & -.352 & .728 \\
\hline & expectations & .497 & .217 & .442 & 2.287 & .029 \\
\hline
\end{tabular}

a. Dependent Variable: $\mathrm{m} 1$

Table 6 shows the $\mathrm{R}$ equals with 67/0 and $\mathrm{R} 2=45 / 0$. Technology components compared to other factors seem to have less impact on the dependent variable. It should be noted that the components of each factor is analyzed separately.

Table 6. Analysis of the operating components impact of technology on the dependent variable

\begin{tabular}{|l|c|l|l|l|}
\hline Model & $\mathrm{R}$ & R Square & $\begin{array}{c}\text { Adjusted R } \\
\text { Square }\end{array}$ & $\begin{array}{c}\text { Std. Error of the } \\
\text { Estimate }\end{array}$ \\
\hline 1 & $.672 \mathrm{a}$ & .451 & .378 & .72441 \\
\hline
\end{tabular}

a. Predictors: (Constant), tech 4, tech 3, tech 2 , tech 1 .

b. Dependent Variable: $\mathrm{m} 1$

Beta coefficients in Table 6 with respect to component complexity - a failure rate of information systems has the most influence on risk.

Table 7. Technology component factors Impact Analysis on the dependent variable 


\begin{tabular}{|c|c|c|c|c|c|c|}
\hline \multirow{2}{*}{\multicolumn{2}{|c|}{ Model }} & \multicolumn{2}{|c|}{$\begin{array}{c}\text { Unstandardized } \\
\text { Coefficients }\end{array}$} & \multirow{3}{*}{$\begin{array}{c}\text { Standardized } \\
\text { Coefficients } \\
\text { Beta }\end{array}$} & \multirow{3}{*}{$\begin{array}{c}\mathrm{t} \\
-1.041\end{array}$} & \multirow{3}{*}{$\begin{array}{r}\text { Sig. } \\
.306\end{array}$} \\
\hline & & \multirow{2}{*}{\begin{tabular}{c}
\multicolumn{1}{c}{$\mathrm{B}$} \\
- \\
1.023
\end{tabular}} & \multirow{2}{*}{$\begin{array}{c}\text { Std. } \\
\text { Error } \\
.983\end{array}$} & & & \\
\hline 1 & (Constant) & & & & & \\
\hline & $\begin{array}{l}\text { Complexity - } \\
\text { Risk }\end{array}$ & .851 & .247 & .557 & 3.452 & .002 \\
\hline & $\begin{array}{l}\text { Impact of } \\
\text { system }\end{array}$ & .044 & .223 & .034 & .199 & .843 \\
\hline & $\begin{array}{l}\text { Schema } \\
\text { System }\end{array}$ & .266 & .197 & .220 & 1.355 & .186 \\
\hline & Infrastructure & .110 & .218 & .077 & .503 & .618 \\
\hline
\end{tabular}

a. Dependent Variable: $\mathrm{m} 1$

\subsection{Analysis Level of All Three Factors on the Failure of Information Systems}

In Table $8, \mathrm{R}$ equal to 0.90 and this means that all components have a direct correlation with dent variable. $\mathrm{R} 2$ also about 0.80 , which shows components of the designed model have been able to explain 0.80 changes of dependent variable. This indicates the power of designed model of this research to demonstrate the failure of information systems in Iranian banks.

Table 8. Analysis of the components of the three factors on the dependent variable

\begin{tabular}{|l|l|l|l|l|}
\hline Model & $\mathrm{R}$ & R Square & \multicolumn{1}{|c|}{$\begin{array}{c}\text { Adjusted R } \\
\text { Square }\end{array}$} & $\begin{array}{c}\text { Std. Error of the } \\
\text { Estimate }\end{array}$ \\
\hline 1 & $.894 \mathrm{a}$ & .799 & .689 & .51184 \\
\hline
\end{tabular}

As can be seen in Table 9, in column of standardized coefficients, beta amount shows the effect of each of these components on the dependent variable.

This study is estimated that strategy factor with (0/438) has the highest impact coefficient and Ingredient of the readiness with (-0/463) has lowest impact coefficient. 


\section{Macrothink}

Business Management and Strategy

ISSN 2157-6068

2013, Vol. 4, No. 2

It means that any management strategy is to implement targeted information systems, information systems will be less chance of failure.in addition the analysis indicate that Organizational readiness for implementing an information system will not have much of a role in the failure of information systems.

Important point in Table 9 of the strategy variable impacts on the success of information systems in Iranian banks is that the amount of 0.438 .

It means that if the objectives and outputs of information systems support organizational goals and strategies, Information systems will be successful and failure chance of them is less.

Table 9. Analysis of the components of the three factors on the dependent variable

\begin{tabular}{|c|c|c|c|c|c|c|}
\hline \multicolumn{2}{|c|}{ Model } & \multicolumn{2}{|c|}{$\begin{array}{c}\text { Unstandardized } \\
\text { Coefficients }\end{array}$} & \multirow{3}{*}{$\begin{array}{c}\text { Standardized } \\
\text { Coefficients }\end{array}$} & \multirow{3}{*}{$\begin{array}{c}\mathrm{t} \\
-.769 \\
\end{array}$} & \multirow{3}{*}{$\begin{array}{l}\text { Sig. } \\
\\
450 \\
\end{array}$} \\
\hline & & \multirow{2}{*}{$\begin{array}{c}\mathrm{B} \\
-.739 \\
\end{array}$} & \multirow{2}{*}{$\begin{array}{c}\text { Std. } \\
\text { Error } \\
.961\end{array}$} & & & \\
\hline 1 & (Constant) & & & & & \\
\hline & Complexity - Risk & .256 & .230 & .167 & 1.114 & .277 \\
\hline & Impact of system & -.017 & .192 & -.013 & -.087 & .932 \\
\hline & Schema System & .050 & .156 & .041 & .319 & .753 \\
\hline & Infrastructure & .194 & .205 & .136 & .946 & .355 \\
\hline & Stability-education & .062 & .143 & .075 & .433 & .669 \\
\hline & support & .198 & .234 & .181 & .848 & .406 \\
\hline & choice & .366 & .232 & .262 & 1.449 & .162 \\
\hline & strategy & .412 & .140 & .438 & 2.941 & .008 \\
\hline & $\begin{array}{l}\text { Comments on } \\
\text { Conflict }\end{array}$ & .124 & .186 & .105 & .664 & .513 \\
\hline & readiness & -.545 & .197 & -.463 & -2.770 & .011 \\
\hline & manner & -.179 & .192 & -.157 & -.933 & .361 \\
\hline & Expectations & .320 & .175 & .284 & 1.827 & .081 \\
\hline
\end{tabular}

5.3 The Pearson Correlation Coefficients between the Components of the Three Factors

\subsubsection{Correlation Coefficient of Management Agent Components}

As mentioned before Management factors include of four components stability - education, support, choice and a strategy. Table 10 shows the Pearson correlation coefficients of these components.

Table 10. correlation coefficient of Management agent components 


\begin{tabular}{|c|l|l|l|l|l|}
\hline & & $\begin{array}{c}\text { Stability-e } \\
\text { ducation }\end{array}$ & support & choice & strategy \\
\hline \multirow{5}{*}{ Stability-education } & Pearson Correlation & 1 & $.685^{* *}$ & $.711^{* *}$ & $.539 * *$ \\
& Sig. (2-tailed) & & .000 & .000 & .001 \\
& $\mathrm{~N}$ & 35 & 35 & 35 & 35 \\
\hline \multirow{3}{*}{ support } & Pearson Correlation & $.685^{* *}$ & 1 & $.763^{* *}$ & $.640^{* * *}$ \\
& Sig. (2-tailed) & .000 & & .000 & .000 \\
& $\mathrm{~N}$ & 35 & 35 & 35 & 35 \\
\hline \multirow{3}{*}{ choice } & Pearson Correlation & $.711^{* *}$ & $.763 * *$ & 1 & $.487 * *$ \\
& Sig. (2-tailed) & .000 & .000 & & .003 \\
& $\mathrm{~N}$ & 35 & 35 & 35 & 35 \\
\hline \multirow{3}{*}{ strategy } & Pearson Correlation & $.539 * *$ & $.640 * *$ & $.487 * *$ & 1 \\
& Sig. (2-tailed) & .001 & .000 & .003 & \\
& $\mathrm{~N}$ & 35 & 35 & 35 & 35 \\
\hline
\end{tabular}

**. Correlation is significant at the 0.01 level (2-tailed).

As you can see the correlation coefficient of stability - education and support components equal to 0/685, which indicates a positive and significant relationship between these two components. If the management stability and managers Information education is more, they support the implementation of information systems more and more.

Correlation coefficient of stability - education and choice components equals with 711/0, which indicates a positive and significant relationship between these two components. It means that if the management stability and managers Information education is more, better team projects will be selected and appropriate information systems in terms of cost - benefit is chosen by the managers.

Correlation coefficient of stability -education and strategy components equal to $0 / 539$, which shows positive and significant relation between these two components. It indicates that if Correlation coefficient of stability - education is more, objectives and outputs of information systems have the greatest support from the organization's goals and strategies.

The table also shows how the correlation between the other components that indicate a high direct and significant correlation between component of the management agent.

\subsubsection{Correlation Coefficient of Components of Technology Agent}

As mentioned before technology agent includes four components of: Complexity - Risk, Impact of system, Schema system, Infrastructure. Table 11 shows the Pearson correlation coefficient of these components. 
Table 11. Correlation coefficient of components of technology agent

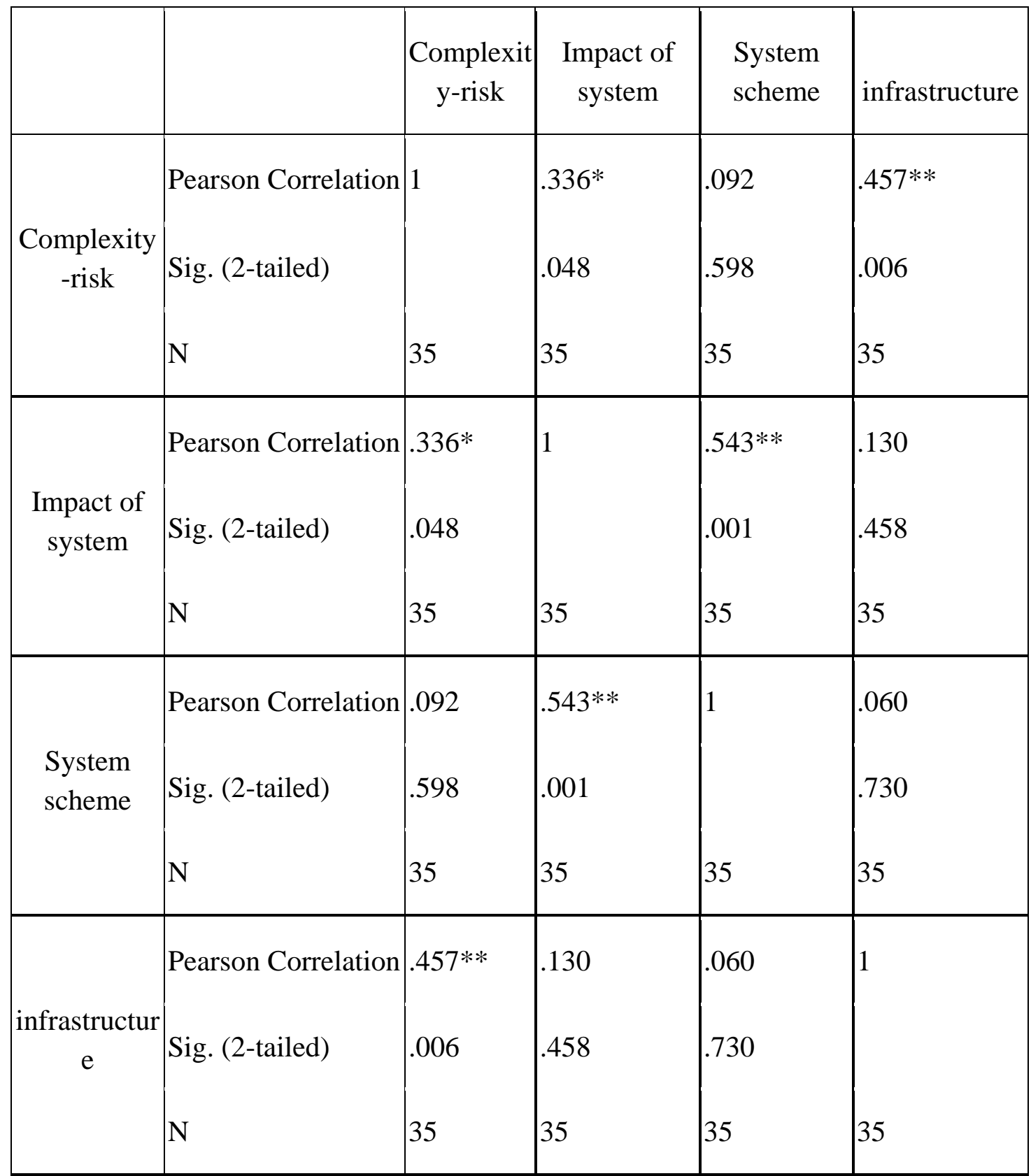

**. Correlation is significant at the 0.01 level (2-tailed).

*. Correlation is significant at the 0.05 level (2-tailed).

As you see Correlation coefficient of complexity - risks and system impact components 0/336, which indicates a direct relationship between these two components is significant but low.it means that there is little relationship between underdevelopment of information systems and reduce manufacturing costs and increase of the financial power due to system implementation.

Correlation coefficient of complexity - risks and system schema components with 0/092, 
indicating no significant relationship is between these two components. This means that we can't make a relationship between the underdevelopment of information systems and determining the information requirements. Correlation coefficient of complexity - risks and infrastructure components is $0 / 457$, which represents a significant and moderate correlation between these two components. It means that there is a relation between underdevelopment of information systems and hardware infrastructure but this is hardly noticeable. This table also shows how the relationship between the other components except the schema infrastructure and complexity -risk and system, there is a relationship between other variables.

\subsubsection{Correlation Coefficient of the Organization Agent Components}

As mentioned before organization agent include for components of: Comments on Conflict. Readiness, Manner and Expectations . Table 12 shows the Pearson correlation coefficient of these components.

Table 12. Correlation coefficient of the organization agent components

\begin{tabular}{|c|c|c|c|c|c|}
\hline & & $\begin{array}{l}\text { Conflicts on } \\
\text { comment }\end{array}$ & readiness & manner & expectation \\
\hline \multirow{3}{*}{$\begin{array}{l}\text { Conflict on } \\
\text { comments }\end{array}$} & Pearson Correlation & 1 & $.520 * *$ & $.414^{*}$ & $.564 * *$ \\
\hline & Sig. (2-tailed) & & .001 & .013 & .000 \\
\hline & $\mathrm{N}$ & 35 & 35 & 35 & 35 \\
\hline \multirow{3}{*}{ readiness } & Pearson Correlation & $.520 * *$ & 1 & .259 & $.476 * *$ \\
\hline & Sig. (2-tailed) & .001 & & .133 & .004 \\
\hline & $\mathrm{N}$ & 35 & 35 & 35 & 35 \\
\hline \multirow{3}{*}{ manner } & Pearson Correlation & $.414^{*}$ & .259 & 1 & $.650 * *$ \\
\hline & Sig. (2-tailed) & .013 & .133 & & .000 \\
\hline & $\mathrm{N}$ & 35 & 35 & 35 & 35 \\
\hline \multirow{3}{*}{ expectation } & Pearson Correlation & $.564 * *$ & $.476 * *$ & $.650 * *$ & 1 \\
\hline & Sig. (2-tailed) & .000 & .004 & .000 & \\
\hline & $\mathrm{N}$ & 35 & 35 & 35 & 35 \\
\hline
\end{tabular}

**. Correlation is significant at the 0.01 level (2-tailed).

*. Correlation is significant at the 0.05 level (2-tailed).

The correlation coefficient between conflict comments and readiness for the design and implementation of information systems with 0.52 that indicates a direct and significant relationship between these two components is a relatively high rate.it means that the consensus between analyst, designer and implementer, with the organization's readiness for implementation of information systems there is a relatively high correlation. . In other words, the more the system is the understanding between the parties; organizations are better 
prepared for the implementation of information systems. Correlation coefficients between conflict on comments and manner equal with0.414 which indicates a direct relationship between these two components is significant. It means relation between understanding of the parties in design and implementing and the system interfaces with employee resistance against the implementation system is relatively moderate. The correlation coefficient is between conflict on comments and components are 0.564 , which indicates a significant relationship between these two components is relatively high. Between the views of the parties involved in the design and implementation of information systems and information systems to meet the expectations of the relationship is relatively high. This table also shows how the relationship between other components between the two components of fitness and the relationship is weak and not significant, but relatively high and there is a significant relationship between other components.

\subsection{Level impact analysis of each of the three factors on the failure of information systems}

As you can see in Table 12, the correlation coefficient of three-factor management, organization and technology of information systems with success and failure in Iranian banks is about 78/0. The $\mathrm{R} 2$ (coefficient of determination) of 605/0, which indicates the explanatory factor (coverage) the in the three factors about dependent variable. Obtained value indicates the high explanatory power of the proposed model.

Table 13. Analysis of each of the three factors on the success of information systems

\begin{tabular}{|l|c|l|l|l|}
\hline Model & $\mathrm{R}$ & R Square & $\begin{array}{c}\text { Adjusted R } \\
\text { Square }\end{array}$ & $\begin{array}{c}\text { Std. Error of the } \\
\text { Estimate }\end{array}$ \\
\hline 1 & $.778 \mathrm{a}$ & .605 & .566 & .60487 \\
\hline
\end{tabular}

As you can see in Table 14, the coefficients of each of these three factors are determined.

Table 14. Analysis of each of the three factors on the success of information systems

\begin{tabular}{|c|c|c|c|c|c|c|}
\hline \multicolumn{2}{|c|}{} & \multicolumn{2}{|c|}{$\begin{array}{c}\text { Unstandardized } \\
\text { Coefficients }\end{array}$} & $\begin{array}{c}\text { Standardized } \\
\text { Coefficients }\end{array}$ & \multirow{2}{*}{ Sig. } & \\
\cline { 2 - 6 } & $\mathrm{B}$ & $\begin{array}{c}\text { Std. } \\
\text { Error }\end{array}$ & Beta & & \\
\hline \multirow{2}{*}{ Model } & (Constant) & -.745 & .887 & & -.840 & .407 \\
\cline { 2 - 7 } & organization & .064 & .065 & .172 & .975 & .337 \\
\cline { 2 - 7 } & technology & .071 & .076 & .141 & .938 & .355 \\
\cline { 2 - 7 } & Management & .159 & .058 & .536 & 2.715 & .011 \\
\hline
\end{tabular}

The beta coefficients in Table 13 Management 0.536 and the technology factor beta coefficient equal to 0.141 . So the management agent and technology agent respectively have most and least impact on the success of information systems in organizations. It is important that the questionnaire was designed, in a separate question; the question was the failure of information systems; as you can see in Table 15, the frequency response shows that $6 / 48$ per 
cent of respondents believe that management agent and technology agent (with 14.3) respectively have most and least impact on the success of information systems in organizations.

Table 15. Frequency of responses in response to the failure of information systems

\begin{tabular}{|rl|l|l|l|l|}
\hline & & Frequency & Percent & $\begin{array}{l}\text { Valid } \\
\text { Percent }\end{array}$ & $\begin{array}{l}\text { Cumulative } \\
\text { Percent }\end{array}$ \\
\hline Valid & 1.00 & 17 & 48.6 & 48.6 & 48.6 \\
\cline { 2 - 6 } & 2.00 & 13 & 37.1 & 37.1 & 85.7 \\
\cline { 2 - 6 } 3.00 & 5 & 14.3 & 14.3 & 100.0 \\
\cline { 3 - 6 } & Total & 35 & 100.0 & 100.0 & \\
\hline
\end{tabular}

\section{Conclusion and Discussion}

It is concluded from Information obtained from the analysis that the most effectiveness factor is management on failure of information system in Iranian bank that serves to customers. These components include a stability factor - education, support, and choice and strategy. It seems to reduce the failure rate of projects rather than focusing too much on operating systems, information technology management in the operating step. This finding results from other reports and studies done about the reasons for the failure to confirm the information systems that Management factor is the most important factors affecting the failure of information systems projects.

The ingredient of the 12 identified, the strategy has the most powerful effect. Information system goals align with organizational goals, one of the influential elements in the success of information systems. This factor is important enough to unaligned the goals of information systems with organizational goals could be causing other failures. So the first goals and strategies, determine, in writing, approved and communicated, and then according to their information systems are designed. Finally, among the components of the management component of the strategy, and among operating components of the component expectations and the operating component technology, component complexity - risky Iranian banks have the most influence on the failure of information systems. So it is strongly recommended that $\mathrm{CEO}$ and CIO manager and Information Systems Analysts on Iranian banks to the items mentioned in the failure of information systems to be aware And the highest investment among the three factors Venture on operating and managing the components from the component 12-fold strategy, expectations and complexity.

Recommended for future studies that identified the components of expert opinion, the objective of information systems projects to be studied and management of communications, technology and organization and how they impact and influence should be investigated.

\section{References}

Akhavan, M., Mohamadlou, M., \& Habibi, J. (2003). Critical factor in the success and failure 
of IT projects. Industrial Studies, 6.

AlSharif, M., Walter, P. B., \& Turkey, A., (2004). Assessing the complexity of software architecture. In Proceedings of the 42nd Annual Southeast Regional Conference (pp. 98-103). http://dx.doi.org/10.1145/986537.986562

Alter, S. (1999). A general, yet useful theory of information systems. Communications of AIS, 1(13), 1-70.

Avison, D., \& Fitzgerald, G. (2003). Information systems development: Methodologies, techniques and tools (3rd Ed.). Berkshire: McGraw-Hill.

Baccarini, D. (1996). The concept of project complexity: A review. International Journal of Project Management, 14(4), 201-204. http://dx.doi.org/10.1016/0263-7863(95)00093-3

Barki, H., Rivard, S., \& Talbot, J. (1993). Toward an assessment of software development risk. Journal of Management Information Systems, 10(2), 203-225.

Braa, J., \& Hedberg, C. (2002). Developing district-based health care information systems. In Proceedings of the IFIP WG9.4 Conference 2000, Cape Town, South Africa. Information flows, local improvisations, and work practices (pp. 113-128). http://dx.doi.org/10.1080/01972240290075048

British Computer Society. (2003, April). The challenges of complex IT projects (Report). The Royal Academy of Engineering.

Cash, C. H., \& Fox, R. (1992). Elements of successful project management. Journal of Systems Management, 43(9), 10-12.

Clark, Steve. (2003), Information systems strategic management,Tehran: Cultural Research bureau.

Cole, A. (1997). Runaway projects - Cause and effects. Software word, 26(3), 3-5.

DeLone, W. H., \& McLean, E. R. (2003). The DeLone and McLean model of information systems success: A ten-year update. Journal of Management Information Systems, 19(4).

Dix, A., Finaly, J., Abword, D., \& Beale, R. (2004). Human-computer interaction (3rd. Ed.). Harlow, UK: Pearson Education Limited.

Garrity, E. J., \& Sanders, L. G. (1998). Information systems success measurement. Hershey, PA: Idea Group Publishing.

Glass, R. (1999). Evolving a new Theory of Project Success: Communications of the ACM, 41(7) November.

Heeks, R. (2000). Failure,success, and improvisation of information systems projects in developing countrrie (Development Informatics Working Paper Series, Paper No. 11). Institute for Development Policy and Management, University of Manchester, UK. Retrieved 
April 1, 2005, from standishgroup.com/sample_research/chaose_1994_2.php

Heeks, R. (2003). E-government for development success and failure rates of e-government in developing/transitional countries: Overview. E-Government for Development Information Exchange IDPM, University of Manchester,UK. Retrieved April 8, 2005, from http://www.egov4dev.org/sfoverview.htm

Irani, Z., Sharif, A. M., \& Love, P. E. D. (2001). Transforming failure into success through organizational learning: An analysis of a manufacturing information system. European Journal of Information Systems, 10, 55-66. http://dx.doi.org/10.1057/palgrave.ejis.3000384

IT Cortex. (2005). Failure rate, Statistics over IT projects failure rate. Retrieved April 10, 2005, from http://www.it-cortex.com/Stat_FailureRate.htm

Jiang, J., \& Klein, G. (1999). Risks to different aspects of system success. Information \& Management, 36(5), 263-271. http://dx.doi.org/10.1016/S0378-7206(99)00024-5

Ketchell, M. (2003, Februrary 28). RMIT to scrap \$47m software system. The Age. Retrieved April 23, 2004, from http://www.theage.com.au/articles/2003/02/27/1046064164879.html

Kitiyadisai, K. (2000). The implementation of IT in reengineering the Thai revenue department. In Proceedings of the IFIP WG9.4 Conference 2000, Cape Town, South Africa. Information flows, local improvisations, and work practices.

Koenig, M. (2003). Knowledge management, user education and librarianship. Library Review, 52(1-2), 10-17. http://dx.doi.org/10.1108/00242530310456979

Laudon, K., \& Laudon, J. (2007). Information Management System.Tehran: Allame Tabatabaei University.

Law, W. K., \& Perez, K. (2005). Cross-cultural implementation of information systems. Journal of Cases on Information Technology, 7(2), 121-130. http://dx.doi.org/10.4018/jcit.2005040108

Liebowits, J. (1999). Information systems: Success or failure? Journal of Computer Information Systems, 40(1), 17-27.

Lyytinen, K., \& R. Hirschheim (1987). Information systems failures: a survey and classification of the empirical literature. Oxford surveys in Information Technology, 4. Oxford University, Press, pp. 257-309.

Montealegre, R., \& Keil, M. (2000). De-escalating information technology projects: lessons from the Denver International Airport. MIS Quarterly, 24(3), 417-447. http://dx.doi.org/10.2307/3250968

Nauman, A., \& Aziz,R and Ishagh, A. F. M. (2009). Information System Development Failure and Complexity: A Case Study. 251-252.

Oz, E., \& Sosik, J. J. (2000). Why information systems projects are abandoned: A leadershop 
and communication theory and exploratory study. Journal of Computer Information Systems, 41(1), 66-78.

Sauer, C. (1993). Why information systems fail: A case study approach. Oxfordshire, UK: Alfred Waller Ltd., Publishers.

Schmidt, R., Lyytinen, K., Keil, M., \& Cule, P. (2001). Identifying software project risks: An international Delphi study. Journal of Management information Systems, 17(4), 5-37.

Seddon, P. B., Staples, S., Patnayakuni, R., \& Bowtell, M. (1999). Dimensions of information systems success. Communications of AIS, 2(3), 2-24.

Standish Group. (1994). The CHAOS report 1994. Retrieved November 30,2006, from http://www.standishgroup.com/sample_research/chaos_1994_1.php

Standish Group. (1999). Project resolution: The 5-year view. Retrieved November 30,2006, from http://www.standishgroup.com/sample_research/PDFpages/chaos 1999.pdf

Standish Group. (2001). Extreme chaos. Retrieved November 30, 2006, from http://www.standishgroup.com/sample_research/PDFpages/extreme_chaos.pdf

Taylor, P. (2000). IT projects: Sink or swim. Computer Bulletin, 42(1), 24-26. http://dx.doi.org/10.1093/combul/42.1.24

Vandersluis, C. (1997). Plan is key to avoiding IT project failures. Computing Canada, 23(9), 20.

Wilson,M., \& Howcroft, D. (2002). Reconstructing failure: Social shaping meets IS research. $\begin{array}{lllll}\text { European Journal of } & \text { Information }\end{array}$ http://dx.doi.org/10.1057/palgrave.ejis.3000437 